\title{
HOXC5 wt Allele
}

National Cancer Institute

\section{Source}

National Cancer Institute. HOXC5 wt Allele. NCI Thesaurus. Code C124122.

Human HOXC5 wild-type allele is located in the vicinity of 12 q13.3 and is approximately 19

$\mathrm{kb}$ in length. This allele, which encodes homeobox protein Hox-C5, is involved in the regulation of gene transcription and anterior-posterior patterning. 